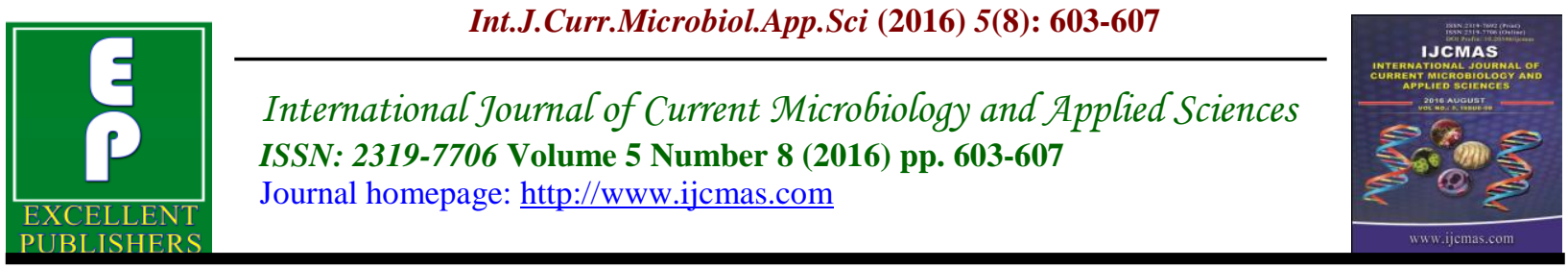

Original Research Article

http://dx.doi.org/10.20546/ijcmas.2016.508.067

\title{
Neonatal Sepsis, Recent Microbiological Agents and their Antibiotic Susceptibility Pattern, Elevated CRP and Other Laboratory Parameter Association
}

\author{
Reena Goyal*, Geeta Tinna, Anjali Gupta and B.P. Sharma \\ Department of Microbiology, S.P. Medical College Bikaner, India \\ *Corresponding author
}

\section{Keywords}

Septicaemia, neonates, Blood culture, antibiogram.

\section{Article Info}

Accepted:

23 July 2016

Available Online:

10 August 2016

\section{A B S T R A C T}

Bacterial infections remain an important cause of paediatric mortality and morbidity. It might be possible to reduce these factors by early diagnosis and proper management. The aim of the study was to analyze the bacteriological profiles with their antibiogram, and to register the risk factors for septicemia in neonates and infants. Setting and design: This study was conducted in a tertiary care teaching hospital at S.P.Medical College, Bikaner, India, and included clinically suspected cases of septicemia in neonates and infants. Blood culture reports were studied in 239 cases of clinically suspected septicemia in neonates and infants, using the standard technique of Mackie and McCartney. The antibiotic sensitivity was performed by Kirby-Bauer's disc diffusion method. Risk factors for sepsis in the children were registered. Elevated CRP, TLC, Band cell count, micro ESR laboratory parameters were taken into account. Blood culture was positive in $45.25 \%$ of cases. Gram-negative septicemia was encountered in $71.42 \%$ of the culture-positive cases. Klebsiella pneumoniae were the predominant pathogens amongst gram-negative organisms in both early \& late onset septicaemia. Amongst the Gram positive organism, Enterococci $(16.67 \%)$ were predominant. Ceftriaxone, third generation cephalosporin, was sensitive only against Enterococcus fecalis while cefoperazone \& cefotaxim both have activity against Klebsiella \& coagulase negative Staphyloccus. ceftazidime was active against Klebsiella, E.coli \& Pseudomonas. CRP levels were elevated in 136 (56.9\%). The most important risk factors of septicemia in our study population were preterm birth (13.49\%). As the cultures showed variable antibiogram with complicated patterns of resistance, culture and sensitivity test should be performed in all cases of septicaemia.

\section{Introduction}

Sepsis is the commonest cause of neonatal mortality, it is responsible for about $30-50 \%$ of the total neonatal deaths in developing countries (Bang et al., 1999; Stoll, 1997). It is estimated that upto $20 \%$ of neonates develops sepsis and approximately $1 \%$ die of sepsis related causes (Baron and Finegold, 1994). The incidence of neonatal 
sepsis according to data from National Neonatal Perinatal Database (NNPD, 20022003) is 30 per 1000 live births. The NNPD network comprising of 18 tertiary care neonatal units across India found sepsis is to be one of the commonest cause of neonatal mortality contributing to $19 \%$ of all neonatal deaths (Report of the National Neonatal Perinatal Database (National Neonatal Forum) 2002 - 03). Among intramural births, Klebsiella pneumoniae was the most frequently isolated pathogen (32.5\%), followed by Staphylococcus aureus (13.6\%). Among extramural neonates (referred from community/other hospitals), Klebsiella pneumoniae was again the commonest organism (27\%), followed by Staphylococcus aureus (15\%) and Pseudomonas (13\%)

Neonatal sepsis is the clinical syndrome characterized by signs and symptoms of infection with or without accompanying bacteremia in first month of life. It encompasses various systemic infections of the newborn such as septicaemia, meningitis, pneumonia, arthritis, osteomylitis and urinary tract infections,

Neonatal sepsis can be classified into two major categories depending upon the onset of symptoms. Early onset sepsis (EOS) - it represent within $72 \mathrm{hrs}$ of life. Infants with EOS usually represent with respiratory distress and pneumonia. Late onset sepsis (LOS) - usually represent after $72 \mathrm{hrs}$ of age. The source of infection in LOS is either nosocomial or community- acquired and neonates usually present with sepsis, pneumonia or meninigitis. The purpose of this study is to identify organism causing these infections along with their antibiotic sensitivity profiles.

The aim of this study includes that the incidence of neonatal septicaemia. And to study the risk factors responsible for development of sepsis. Also to study the recent pattern of microbiological agents responsible for neonatal septicaemia.

\section{Materials and Methods}

This prospective study was conducted on neonates born in women's hospital, S.P.Medical College, Bikaner and admitted to the N.I.C.U attached to Department of Paediatrics, S.P.Medical College and Associated Group of Hospitals, Bikaner.

\section{Inclusion criteria}

239 clinically suspected cases of septicaemia in neonates and infants and two or more laboratory criteria or culture positive were included in study. Signs and symptoms of sepsis included: temperature instability, feeding difficulties, respiratory distress, jaundice, convulsions and autonomic disturbances. Laboratory criteria were : (1) Total leucocyte counts $(<5000$ or $>20000 / \mathrm{mm}^{3}$.(2) band cell count more than $20 \%$ (3) band cell / absolute neutrophil counts ratio $(>0.2 \%)$ (4) elevated $\mathrm{C}$ - reactive protein $(>6 \mathrm{mg} / \mathrm{l})(5)$ micro ESR $(>10 \mathrm{~mm}$ in $1^{\text {st }} \mathrm{hr}$ ) (6) Blood culture positive.

\section{Sample collection and processing}

After taking permission from parents 1- $2 \mathrm{ml}$ blood was collected from a peripheral vein of neonates and infants using proper aseptic precautions and inoculated immediately into $5 \mathrm{~mL}$ of glucose broth with $0.025 \%$ Sodium polyanethol sulfonate as anticoagulant (HiMedia Laboratories, Mumbai). Blood cultures were processed using the standard technique described by Mackie and McCartney (Collee et al., 1996). The bottle was incubated at $37^{\circ} \mathrm{c}$. After $24 \mathrm{hrs}$ subcultures were done on blood agar and MacConkey's medium for next $24 \mathrm{hrs}$. A negative result was followed up by examining the broth daily and doing a final 
subculture at the end of 7 days or at appearance of turbidity, whichever was earlier. Aerobic isolates were studied. Any growth was identified by colonial characteristics, Gram staining, and standard biochemical tests (Baron et al., 1994). Antimicrobial susceptibility testing was performed by the Kirby-Bauer disc diffusion method as per the NCCLS recommendations (Performance Standards for antimicrobial susceptibility testing, Eighth Information Supplement, 2000.).

\section{C-reactive protein (CRP)}

Estimation was done by qualitative slide agglutination test. If CRP conc. Is greater than $6 \mathrm{mg} / \mathrm{L}$ a visible agglutination is observed and if CRP conc. less than $6 \mathrm{mg} / \mathrm{L}$, then no agglutination is observed

Other laboratory tests were also taken into account

\section{Results and Discussion}

239 newborns, clinically suspected of sepsis were selected for the study. Septicaemia was suspected according to clinical feature and proved by positive blood culture or $\geq 2$ positive lab criterias (Table-1). The overall incidence of sepsis was higher in preterm $(13.49 \%)$ as compare to full term $(4.76 \%)$. The incidence was higher in males $(65.27 \%)$ as compare to females (43.72\%). This may be due to factors regulating the synthesis of gammaglobulin are probably situated on $\mathrm{X}$ chrosomes in the male infants thus confers less immunological protection compare to female counterpart(7) Early onset septicaemia was more common. it was present in $69.03 \%$ cases while late onset septicaemia was present in $30.96 \%$.

Gram negative organism were more common $(71.42 \%)$ than Gram positive $(28.57 \%)$ in blood culture positive cases (Table -2). Klebsiella was the most common pathogen (48.21\%) in both early and late onset septicaemia. Other Gram negative bacilli recovered were Citrobacter, E.coli, and others. Pseudomonas was recovered in single case. Amongst the Gram positive organism, enterococci $(16.67 \%)$, coagulase negative staphyloccus $(8.92 \%)$ were recovered. MRSA was documented in three cases ( Table-3).

Table.1 Correlation of blood culture sensitivity with laboratory criterias

\begin{tabular}{|l|l|l|l|l|l|}
\hline $\begin{array}{l}\text { Laboratory } \\
\text { Criteria } \geq 2\end{array}$ & Laboratory & & \\
\hline $\begin{array}{l}\text { Blood } \\
\text { culture } \\
\text { positive }\end{array}$ & $\begin{array}{l}\text { Blood } \\
\text { culture } \\
\text { negative }\end{array}$ & Total & $\begin{array}{l}\text { Blood } \\
\text { culture } \\
\text { positive }\end{array}$ & $\begin{array}{l}\text { Blood } \\
\text { culture } \\
\text { negative }\end{array}$ & Total \\
\hline $52(45.21 \%)$ & $\mathbf{6 3}$ & 115 & $\mathbf{4}(3.22 \%)$ & 120 & 124 \\
\hline
\end{tabular}

Table.2 Distribution of culture positive cases according to Gram Staining

\begin{tabular}{|l|l|l|}
\hline Gram staining & No. of cases & Percentage \\
\hline Gram positive & 16 & $28.57 \%$ \\
\hline Gram negative & $\mathbf{4 0}$ & $\mathbf{7 1 . 4 3 \%}$ \\
\hline Total & $\mathbf{5 6}$ & $\mathbf{1 0 0 \%}$ \\
\hline
\end{tabular}


Table.3 Distribution of etiological agents according to age of onset

\begin{tabular}{|l|c|c|c|}
\hline Organism & Early onset & Late onset & Total \&\% \\
\hline Klebsiella & 18 & 9 & $\mathbf{2 7}(\mathbf{4 8 . 1 \% )})$ \\
\hline Enterococcus fecalis & 7 & 2 & $\mathbf{9 ( 1 6 . 0 7 \% )}$ \\
\hline $\begin{array}{l}\text { Coagulase negative } \\
\text { Staph. } \text { Aureus }\end{array}$ & 3 & 2 & $5(8.92 \%)$ \\
\hline Citrobacter & 3 & 2 & $5(8.92 \%)$ \\
\hline E. coli & 1 & 1 & $2(3.57 \%)$ \\
\hline $\begin{array}{l}\text { Other gram } \\
\text { negative bacilli }\end{array}$ & 0 & 3 & $3(5.35 \%)$ \\
\hline MRSA & 0 & 3 & $3(5.35 \%)$ \\
\hline Pseudomonas & 0 & 1 & $1(1.78 \%)$ \\
\hline Klebsiella and E.coli & 0 & 1 & $1(1.78 \%)$ \\
\hline
\end{tabular}

Table.4 Bacterial isolates and their sensitivity to various antibiotics

\begin{tabular}{|c|c|c|c|c|c|c|c|c|c|c|c|c|c|c|c|c|}
\hline $\begin{array}{c}\text { Micro- } \\
\text { organism }\end{array}$ & $\begin{array}{l}\text { No. of } \\
\text { cases }\end{array}$ & 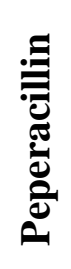 & שِ & لِّ & Ũ & 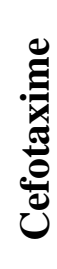 & 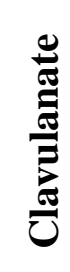 & • & 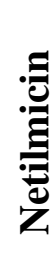 & 递 & & 苗 & 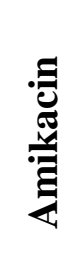 & & 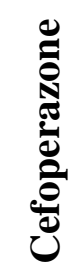 & $\begin{array}{l}\text { Resistant } \\
\text { to all } \\
\text { antibiotics }\end{array}$ \\
\hline Klebsiella & 27 & - & + & + & - & + & + & - & + & + & - & - & + & - & + & 6 \\
\hline $\begin{array}{l}\text { Enterococcus } \\
\text { fecalis }\end{array}$ & 9 & + & - & - & + & + & - & + & - & - & + & + & - & + & - & - \\
\hline CONS & 5 & + & - & - & - & + & - & + & - & + & - & + & + & + & + & - \\
\hline E.coli & 2 & - & - & + & - & - & + & - & - & - & + & - & + & - & + & - \\
\hline Citrobacter & 5 & - & - & - & - & + & - & - & - & - & - & - & - & - & - & - \\
\hline Other GNB & 3 & - & + & + & - & + & - & - & - & - & + & - & + & - & - & - \\
\hline MRSA & 3 & - & - & - & - & - & - & + & - & - & + & - & - & - & - & - \\
\hline Pseudomonas & 1 & + & - & + & - & - & - & - & - & - & + & - & - & - & - & - \\
\hline Kleb. \& E.coli & 1 & - & - & - & - & - & - & - & - & - & - & - & - & - & - & - \\
\hline
\end{tabular}

Table.5 Laboratory investigation in suspected cases of neonatal septicaemia

\begin{tabular}{|l|l|l|l|}
\hline Investigation & Present & Absent & No. of cases \\
\hline TLC & $103(43.09 \%)$ & 136 & 239 \\
\hline $\begin{array}{l}\text { Band cell : ANC } \\
\text { ratio }\end{array}$ & $99(41.4 \%)$ & 140 & 239 \\
\hline m - ESR & $85(35.5 \%)$ & 154 & 239 \\
\hline CRP & $136(56.9 \%)$ & 103 & 239 \\
\hline
\end{tabular}

The present study, showed alarming results of antibiotic sensitivity patterens. The antibiotics which are commonly used like ampicillin and ceftriaxone showed poor activity against most of the organism. Only Streptococcus fecalis was sensitive against 
ceftriaxone. Cefoperazone and cefotaxim both have activity against Klebsiella and coagulase negative staphylococcus. Ceftazidime shown better results and active against Klebseilla, E.coli, Pseudomonas and other gram negative bacilli. Piperacillin had advantage over ampicillin. All organism except E.coli showed sensitivity to cefotaxime. Out of 27 Klebseilla isolate 6 were resistant to all antibiotics. Citrobactor was only sensitive to cefotaxim (Table -4) The antimicrobial sensitivity pattern differs in different studies as well as at different times in the same hospital in Indian and overseas studies. This is mainly a result of indiscriminate use of antibiotics.

In suspected cases of septicemia other deranged laboratory parameters, increased CRP (56.9\%), deranged total leukocyte count $(43.09 \%)$, band cell: ANC ratio $(41.4 \%)$ and micro-ESR $(35.5 \%)$ were present (Table-5).

In conclusions, systemic bacterial infection in the newborn creates a significant burden due to its impact on neonatal mortality and long-term morbidity. In spite of ongoing efforts in early diagnosis, treatment, and prevention, neonatal sepsis still remains an enigmatic area for neonatologists due to changes in epidemiology and the lack of ideal diagnostic markers. As the cultures showed variable antibiogram with complicated patterns of resistance, culture and sensitivity test should be performed in all cases of septicemia.

\section{References}

Bang, A.T., Bang, R.A., Bactule, S.B., Reddy, H.M., Deshmukh, M.D. 1999. Effect of home-based neonatal care and management of sepsis on neonatal mortality: field trial in rural India, Lancet, 354: 1955 - 61.

Baron, E.J., Finegold, S.M. (Eds). 1994. Overview of conventional methods for bacterial identification. Chapter 13, In: Bailey and Scott's Diagnostic Microbiology (Mosby Publishers, St. Louis) 167.

Collee, J.G., Marr, W. 1996. Mackie and McCartney Practical Medical Microbiology. In: Collee JG, Fraser AG, Marmion BP, Simmons A, editors. Culture of Bacteria. 14th ed. New York: Churchill Livingstone; pp. 113-29.

Performance Standards for antimicrobial susceptibility testing. Eighth Information Supplement, 2000. National Committee for Clinical Laboratory Standards (NCCLS). M2A7 Vol. 20, No. 1 and 2, Villanova.

Report of the National Neonatal Perinatal Database (National Neonatal Forum) $2002-03$.

Stoll, B.J. 1997. The global impact of neonatal infection. Clin. Perinatol., 24: $1-21$.

\section{How to cite this article:}

Reena Goyal, Geeta Tinna, Anjali Gupta, B.P. Sharma. 2016. Neonatal Sepsis, Recent Microbiological Agents and their Antibiotic Susceptibility Pattern, Elevated CRP and Other Laboratory Parameter Association. Int.J.Curr.Microbiol.App.Sci. 5(8): 603-607. doi: http://dx.doi.org/10.20546/ijcmas.2016.508.067 